\title{
AVALDUSTE TEKSTISTRATEEGIAD
}

\author{
RIINA REINSALU
}

Annotatsioon. Avalduse kui tekstiliigi suhtluseesmärk väljendub avalduse esitaja soovis mõjutada avalduse saajat tegema mõnd tegu kas enda või kellegi teise huvides. Selleks tuleb valida sobiv tekstistrateegia, mis väljendub teksti astmelises struktuuris ja eripärases keelekasutuses. Artikli allikmaterjali moodustavad 19 avaldust, mis on esitatud Sauga vallavalitsusele ja vallavolikogule ajavahemikus 5.-13. jaanuarini 2011. Eesmärk on välja selgitada, mis tekstistrateegiat rakendavad kodanikud avalduste kaudu ametiasutusega suhtlemisel. Uurimistulemustest ilmneb, et vaatlusalused avaldused on võrdlemisi jäiga sisemise struktuuriga, mis tuleneb ühtaegu nii kultuuritavadest kui ka suhtlusolukorrast. Tegu, mida kohalikult omavalitsuselt oodatakse, on enamasti vormistatud kas palve või soovina, üksikjuhtudel ka ettepaneku või käsuna.

Võtmesõnad: ametikeel, struktuurianalüüs, žanr, žanrianalüüs, eesti keel

\section{Sissejuhatus}

Ametisuhtluse paremaks korraldamiseks koostatakse mitmesuguseid tekste. Osa neist on mõeldud üksnes teabe talletamiseks (nt tõendid, protokollid, aruanded), teise osaga aga kujundatakse inimeste tegevust (nt teabenõuded, avaldused, taotlused). Et tekst täidaks oma eesmärki võimalikult hästi, on vaja rakendada sobivat tekstistrateegiat. Nii näiteks tuleb inimeste tegevust suunavaid tekste luues otsustada, mil viisil on kõige otstarbekam tegu väljendada: kas esitada see vihje, soovi, nõude, loa, käsu, ettepaneku või muul kujul.

Strateegia valik oleneb kultuuri- ja situatsioonikontekstist. Kultuurikontekst väljendub tekstiliigi ehk žanrina ja situatsioonikontekst registrina (Martin 2001: 155). See tähendab, et loodav tekst peab ühtaegu vastama nii kultuuritavadele, mis avalduvad näiteks teksti ülesehituses, kui ka suhtlusolukorrale, mida mõjutavad käsitletav teema, osalised ja nende rollid ning suhtluskanal. Vaid sel viisil on võimalik jõuda teksti suhtluseesmärgile ja määrata teksti žanrikuuluvus. 
Selles artiklis ${ }^{1}$ võtan vaatluse alla ametitekste esindavad avaldused. Kuna avaldused erinevad nii vormilt (blankett vs. vaba vorm) kui ka sisult, täidavad need mõnevõrra erinevat suhtluseesmärki, mistõttu tuleb avaldust käsitleda üldžanrina. Üldžanr väljendab küll žanri põhitunnuseid, võimaldades teha üldistusi ja pakkudes rakendusvõimalusi, kuid üksikasjalikud žanriomadused ilmnevad madalamal tasandil - olukohaste žanrite kaudu (žanrite hierarhilist liigitust vt Puksand, Kerge 2012). Olukohast žanrit esindavad praegusel juhul artikli allikmaterjaliks olevad avaldused, mis on kirjutatud vabas vormis ja mida seob ühine teema (rahulolematus vallavalitsuse otsusega muuta valla üldplaneeringu kavandit). Et eristada neid avaldusest kui üldžanrist, kasutan nende tähistamiseks tinglikku nimetust kaebeavaldus.

Artikli allikmaterjali teeb eripäraseks asjaolu, et tavaliselt on avaldused mõeldud asutusesiseseks kasutuseks, mistõttu on nende kohta kehtestatud ligipääsupiirang, seevastu vaatlusalused avaldused on veebis vabalt kättesaadavad. Ligipääsupiirang võib olla üks põhjuseid, miks pole avaldusi varem Eestis keeleteaduslikult käsitletud, kuid peamine põhjus on nähtavasti asjaolu, et ametikeel tervikuna ei kuulu peavoolu uurimisteemade hulka. Erandiks on ametikirjad, mille puhul on uuritud nii struktuuri (Pullerits 2005; Rätsep 2006), arusaadavust (Ratassepp 2016) kui ka mitmesuguseid keeleparameetreid (Kerge 2010; Tomiste 2012). Seevastu suuremat tähelepanu on pälvinud avaldused rakenduslikust aspektist, sest avaldus kuulub nende tekstiliikide hulka, mille kirjutamist õpetatakse ametikeele koolitustel ja keelekäsiraamatutes, nt Maire Raadiku raamatus „Väikesed tarbetekstid“(2014).

Artikli eesmärk on välja selgitada avalduste (resp. kaebeavalduste) tekstistrateegiad, võttes aluseks kaks uurimisküsimust: milline on vaatlusaluste avalduste sisestruktuur ja mis keelevahendite abil püüavad avalduste esitajad kujundada avalduse saaja tegevust? Avalduste analüüsimisel tuginen John Malcolm Swalesi (1990) kaheastmelisele mudelile ning lähtun eeldusest, et avalduste sisestruktuur koosneb nii obligatoorsetest kui ka fakultatiivsetest osadest, mida iseloomustavad eripärased tekstimustrid. Kuna avalduse esitaja on kodanik ja avalduse saaja ametiasutus (Sauga vallavalitsus), siis annab nii struktuuri kui ka tekstimustrite analüüs aimu

Artikkel põhineb 11. detsembril 2015 Tartu Ülikoolis toimunud tekstipäeva ettekandel. 
kodaniku ja ametiasutuse suhtluse tavadest ning osutab võimalikele võimusuhetele.

\section{Teoreetilised pidepunktid}

Žanriuurimises on kujunenud välja kolm koolkonda: James Robert Martini juhitav Sydney koolkond, kelle uurimisobjekt on süsteemfunktsionaalne grammatika (ingl systemic functional linguistics), John Swalesi ja Vijay Kumar Bhatia žanriteoreetilistest põhimõtetest juhinduv erialase inglise keele (ingl English for specific purposes) koolkond, kes on keskendunud eeskätt struktuuriuuringutele, ning Carolyn Milleri ja Amy Devitti eestvedamisel tegutsev Põhja-Ameerika retooriliste žanriuuringute (ingl rhetorical genre studies) koolkond, kes vaatleb žanri kui sotsiaalse tegevuse retoorilisi funktsioone (ülevaadet koolkondadest vt nt Hyon 1996; Bawarshi, Reiff 2010). ${ }^{2}$ Kuigi need koolkonnad erinevad oma uurimisfookuse (teksti ja konteksti vahekorra), uurimismeetodite ja pedagoogilise suunitluse poolest (Hyland 2002: 113-114), on neil teatav ühisosa. Nimelt jagavad nad arusaama, et žanr kui retooriline kategooria esindab sotsiaalselt määratud suhtlust, mis ei toimu isolatsioonis, vaid on mõjutatud teistest žanritest ja tekstidest (intertekstuaalsus), samuti pildist, helist jms (multimodaalsus) ning mis peegeldab ja kujundab muu hulgas võimusuhteid (Tardy 2013: 55).

Selle artikli teoreetiliseks alustalaks on Swalesist ja Bhatiast lähtuv žanriuurimise traditsioon, mille kohaselt määrab žanri olemuse selle kogukondlikult tunnustatud suhtluseesmärk, mis mõjutab nii žanri sisestruktuuri kui ka kasutatavaid keelevahendeid (Swales 1990: 58). Suhtluseesmärgi seadmist žanri tuumaks on kritiseeritud peaasjalikult kahest aspektist. Esiteks, žanri identifitseerimist suhtluseesmärgi järgi, nagu Swales seda teeb, raskendab asjaolu, et peale standardse eesmärgi võib žanr täita ka individuaalseid eesmärke, samuti võib juhtuda, et kogukonna liikmed ei ole žanri põhieesmärgi suhtes ühel meelel (Lassen 2006: 504-505). Erinevalt Swalesist möönab Bhatia (1993: 13) küll mitme eesmärgi, sh

2 Klassikaliste koolkondade žanrikäsitlusi, mille algusaeg jääb 1970. ja 1980. aastatesse ning kõrgaeg 1990. aastatesse, on aja jooksul edasi arendatud. Välja on kujunenud kaks uut suunda - Brasiilia žanriuuringud ja akadeemilise kirjaoskuse liikumine (nn uus Londoni koolkond) -, mis pretendeerivad samuti koolkonna staatusele (Swales 2012: 113). 
varjatud eesmärkide võimalikkust, kuid tema suhtluseesmärkide käsitlus jääb konkreetsete žanrite eristamiseks liiga üldiseks (Askehave 1999: 16).

Tunnistades suhtluseesmärgiga kaasnevaid raskusi, on Swales oma hilisemates käsitlustes žanrianalüüsi fookust muutnud. Suhtluseesmärk säilitab küll oma privilegeeritud staatuse, olles nii tekstist kui ka kontekstist johtuva žanrianalüüsi osa, kuid mitte enam siht omaette, millele kogu žanrianalüüs on rajatud (Askehave, Swales 2001: 209-210). Tekstitasandi eesmärgi analüüsimise asemel püütakse eri meetodeid kombineerides sügavuti kirjeldada, mõista ja selgitada, kuidas ja miks mingi eriala esindajad loovad, levitavad ja rakendavad oma eriteadmisi, et saavutada laiem ametialane eesmärk. Selline rõhuasetus võimaldab žanrianalüüsi vaadelda (ühiskonna)kriitiliste uuringute raamistikus. (Bhatia 2015: 14)

Kuigi kriitilise žanrianalüüsi fookus on nihkunult tekstilt kontekstile (Bhatia 2008: 166), ei märgi see täielikku loobumist tavapärasest struktuurianalüüsist. Teksti astmelise struktuuri analüüs (ingl move structure analysis või move analysis), mille käigus selgitatakse välja teksti autori kavatsuste aluseks olevad käigud (ingl moves) ja vajaduse korral ka sammud (ingl steps), mis ilmnevad kas lausest või muudest tekstiosadest või tekstis sisalduvast mitteverbaalsest teabest (Tardy, Swales 2014: 168), moodustab ka praegu osa kriitilisest žanrianalüüsist, kuid tulemuste esitamisel keskendutakse tekstivälistele teguritele. Struktuurianalüüsi rakendatakse teadustekstide ja nende osade (iseäranis annotatsioonide, sissejuhatuste) uurimisel, inspireerituna Swalesi varasematest töödest, samuti on žanriuurimises endiselt esindatud Bhatia-mõjuline ametitekstide uurimise suund, mille objektiks on peale kirjažanrite (nt motivatsioonikirja, ärikirja) ka mitmesugused muud ametlikku suhtlust esindavad žanrid. Eestis on tekstiuurijad rakendanud Swalesi ja Bhatia žanriteoreetilisi käsitlusi peamiselt žanri mõiste avamiseks - nt Kersti Lepajõe (2011) on käsitlenud kirjandit ja Riina Reinsalu (2011) lepingut kui tekstiliiki -, kuid mitte struktuuri analüüsimiseks.

\section{Allikmaterjal ja meetod}

Artikli allikmaterjali moodustavad 19 avaldust, mis on esitatud ajavahemikus 5.-13. jaanuarini 2011 Sauga vallavalitsusele ja vallavolikogule (esialgne valim koosnes 22 avaldusest, kuid kolm korduva sõnastusega avaldust jätsin lõplikust valimist välja). Avaldused on PDF-vormingus 
ja kuni ühe lehekülje pikkused ning pärinevad Sauga valla veebilehelt ${ }^{3}$. Ligipääsupiirangu puudumine teeb neist eripärase uurimismaterjali, sest üldjuhul sisaldavad avaldused delikaatseid isikuandmeid, mistõttu on need mõeldud üksnes asutusesiseseks kasutuseks.

Avalduste analüüsimisel rakendasin Swalesi (1990) käikude ja sammude mudelit. Esimeses etapis selgitasin välja iga vaatlusaluse artikli retoorilised käigud (tekstiosade eesmärgid), mis toetavad žanri üldeesmärkide täitmist. Seejärel tuvastasin funktsionaalsed sammud, mille kaudu viiakse käik kindlas järjekorras ellu. Teises etapis võrdlesin avaldusi omavahel ja koostasin loetelu tunnustest, mis on vaatlusalusele žanrile omased ja moodustavad kindla mustri. Selle tulemusena moodustus kolmest käigust ja kolmest sammust koosnev mudel, mida käsitlen üksikasjalikult järgmises peatükis. Tulemused esitan koos tõlgendustega.

\section{Struktuurianalüüs}

Et avaldus tekstiliigina täidaks oma suhtluseesmärki võimalikult hästi, peab see vastama väljakujunenud tavadele. Kuna avalduse peamine eesmärk on tegu - keegi peab kellegi palvel, soovil, ettepanekul või nõudmisel midagi tegema -, siis on ootuspärane, et avaldustes esitatakse kõigepealt adressaat (koos postiaadressiga), kelleks on praegusel juhul Sauga vallavalitsus või vallavolikogu, ja seejärel dokumendi pealkiri. Peale avalduse (nt Avaldus seoses Sauga tuulepargiga) on pealkirjana kasutatud ka nimetusi ettepanek (nt Ettepanek Üldplaneeringu koostamisele) ja taotlus (Taotlus üldplaneeringu muutmiseks). Kuna nende sisu on sama, siis võib nimetuste erinevusest hoolimata liigitada vaatlusalused tekstid üheks tekstiliigiks. Vahel järgneb tekstiliigi nimetusele pöördumisvormel (nt Lugupeetud Vallavalitsus, Austatud Vallavolikogu), kuid enamasti pole peetud vajalikuks seda avaldusse lisada, sest adressaat on eespool juba nimetatud. Avalduse üla- või alaosast leiab ka avalduse esitamise kuupäeva ning sisuosa lõpust viisakusvormeli Lugupidamisega. Viisakusvormelile järgnevad avalduse kirjutaja nimi ja allkiri, mõnel juhul ka isikuandmed.

Avalduste sisestruktuur on lihtsakoeline, koosnedes kolmest käigust ja kolmest sammust. Ülevaade käikudest ja sammudest koos näidetega on esitatud tabelis. Iga käigu ja sammu järel on sulgudes toodud nende avalduste arv, milles need esinesid.

\footnotetext{
3 http://www.sauga.ee/Kirjad-paerast-15-12-2010-arut.342.0.html.
} 
Tabel. Avalduste astmeline struktuur

\begin{tabular}{|c|c|c|}
\hline Käigud & Sammud & Näited \\
\hline \multirow{3}{*}{$\begin{array}{l}\text { 1. käik: } \\
\text { taustteabe } \\
\text { esitamine (19) }\end{array}$} & $\begin{array}{l}\text { 1. samm: aja ja } \\
\text { koha väljendamine } \\
(19)\end{array}$ & $\begin{array}{l}15 \text { detsembril } 2010 \text { a. toimus Urge raama- } \\
\text { tukogus Sanga Üldplaneeringu koostamise } \\
\text { tutvustav koosolek, kus arutati Sanga valda } \\
\text { tuulegeneraatorite rajamise võimalusi. }\end{array}$ \\
\hline & $\begin{array}{l}\text { 2. samm: enda } \\
\text { seotus kõnealuse } \\
\text { probleemiga (19) }\end{array}$ & $\begin{array}{l}\text { Minule kuulub kinnistu Pärnumaal, Sanga } \\
\text { vallas, Rütavere külas Vanamõisa kinnistu, } \\
\text { katastriüksuse numbriga 73001:007:0158. }\end{array}$ \\
\hline & $\begin{array}{l}\text { 3. samm: } \\
\text { probleemi } \\
\text { kirjeldamine (19) }\end{array}$ & $\begin{array}{l}\text {... jääb arusaamatuks, miks on Sauga } \\
\text { Vallavalitsus vähendanud tuulepargi terri- } \\
\text { tooriumi vorrreldes } 10.06 .2009 \text { välja käidud } \\
\text { üldplaneeringu lahendusega. }\end{array}$ \\
\hline \begin{tabular}{l|} 
2. käik: \\
enda seisukoha \\
rõhutamine (13)
\end{tabular} & & $\begin{array}{l}\text { Teatame, et ei nõustu selline planeeringula- } \\
\text { henduse mundatusega. }\end{array}$ \\
\hline $\begin{array}{l}\text { 3. käik: } \\
\text { soovitava teo } \\
\text { nimetamine } \\
(19)\end{array}$ & & $\begin{array}{l}\text { Eeltoodust tulenevalt palun Sauga Valla- } \\
\text { valitsusel arvestada inimeste õiguspärast } \\
\text { ootust ning mitte vähendada } 10.06 .2009 \text { a. } \\
\text { esitletud Valla üldplaneeringu lahendust } \\
\text { reserveeritud tuulepargi piirkonna osas. }\end{array}$ \\
\hline
\end{tabular}

Tüüpilisim on kolmekäiguline struktuurimudel: kõigepealt esitatakse taustteave, seejärel oma seisukoht kõnealuses küsimuses ja viimaks soovitav tegu, liikudes ajaliinis minevikust olevikku ja tulevikku. Vahel piirdub avalduse kirjutaja kahe käiguga, jättes oma seisukoha otsesõnu väljendamata. Olenemata käikude arvust nimetatakse soovitav tegu avalduse sisuosa viimases lauses või lõigus. Sellega pannakse kogu loole selge punkt, teo tähtsust rõhutatakse ka poolpaksu kirjaga.

Erinevalt käikudest võib sammude järjekorras täheldada suuremat varieeruvust. Enamasti osutatakse avalduse avalauses, millal ja kus probleem ilmnes või kuidas on avalduse esitaja kõnealuse probleemiga seotud. Seevastu probleemi olemust selgitatakse alati viimase sammuna enne teist käiku ehk enne oma seisukoha väljendamist või soovitava teo nimetamist. 


\subsection{Taustteabe esitamine}

Esimene käik koosneb kolmest sammust: 1) aja ja koha väljendamine detsember 2010, Urge raamatukogu veebileht või valla veebileht; 2) enda seotus kõnealuse probleemiga - avalduse esitajale kuulub kinnistu, kuhu plaaniti püstitada tuulik; 3) probleemi kirjeldamine - vallavalitsus muutis üldplaneeringut nii, et avalduste esitajate kinnistud jäid tuulepargi alalt kas osaliselt või täielikult välja. Kui aega ja kohta väljendatakse neutraalselt (näide $1^{4}$ ), siis enda seotuse esitamisel apelleeritakse avalduse adressaadi tunnetele, näidates end kannatanu rollis. Üldplaneeringu muutmisest tulenevad kannatused seisnevad materiaalses kahjus (näide 2).

(1) Sauga vald on oma koduleheküljele lisanud muudetud Sauga valla üldplaneeringu kaardi. Muudatus võrreldes varajasemate Sauga Valla üldplaneeringu lahendustega puudutab eeskätt tuulegeneraatoritele mõeldud territooriumi.

(2) Kuna antud kinnistu oli esialgse hinnang kohaselt tuulegeneraatorite püstitamiseks sobilik, tegin sellest tulenevalt kinnistuga seoses ka erinevaid kulutusi nagu notariaalse hoonestusõiguse seadmise lepingu, mõõdistamine jne. Vastasel juhul oleksin antud kinnistuga seotud plaane teinud teisiti.

Viimasest näitest ilmneb, et avalduse kirjutaja ei ole olukorraga rahul, kuid ta ei väljenda oma pahameelt sõnaselgelt, vaid vihjamisi. Kuigi ta kirjeldab olukorda kannatanu positsioonilt, ei tembelda ta vallavalitsust süüdlaseks. Seevastu enamik kinnistuomanikest rakendab ründavamat taktikat: kuna vallavalitsuse otsus teha muudatus üldplaneeringus muutis nende kui maaomanike olukorda ja tõi kaasa vajaduse esitada avaldus, siis kasutavad nad probleemi kirjeldades võimalust väljendada oma rahuolematust. Kinnistuomanikud ei saa aru, miks üldplaneeringu muudatus on vajalik (näited 3-5), ja avaldavad selle üle imestust (näide 6) või tunnevad kahju (näide 7), kritiseerides vallavalitsuse tegevust kaude, enda tundmuste kirjeldamise kaudu. Ühel juhul markeeritakse imestust hüüumärgiga (näide 8). Rangema hinnanguna mõjub aga sõna põhjendamatu või põhjendamatult - sel juhul ei ole fookus enda subjektiivsetel tundmustel, vaid objektiivsematel, nt õigusaktidest või uuringutest tulenevatel alustel (näide 9).

${ }^{4}$ Kõik näited on esitatud muutmata kujul. Esiletõstuvahendina olen kasutanud kursiivkirja ja lühendamiseks katkestuspunkte. 
(3) Jääb arusaamatuks, miks on järsku selline muudatus toimunud.

(4) Koosolekul esitleti uut Sauga valla üldplaneeringu lahendust, mis on aga varajasematega võrreldes millegipärast oluliselt muudetud.

(5) 15.12.2010 a. toimunud Sauga valla tuulepargi tutvustaval koosolekul tekitas aga segadust asjaolu, et Sauga Vallavalitsus oli lauale asetanud 2 erinevat kaarti ..

(6) Minu suureks üllatuseks oli 15.12.2009 a. Urge küla raamatukogus toimunud uuel Sauga valla üldplaneeringu kaardil nimetatud kinnistud tuulegeneraatorite püstitamiseks sobivatest aladest välja jäetud.

(7) Kahjuks tuleb tõdeda, et tuuleenergeetika arenduseks sobivatest aladest jäeti välja ka minule kuuluv Raja kinnistu.

(8) Nüüd, uue lahenduse järgi, ei jää minule kuuluv kinnistu .. üldplaneeringus tingmärgiga ,maatulundusala, kuhu on lubatud rajada tuuleelektrijaamu" piirkonda!

(9) On põhjendamatu vähendada tuulepargi ala võimalikku piirkonda põhjustel, mis on üksnes subjektiivsed ja teoreetilised.

Kuna avaldusi kirjutatakse tavaliselt enda nimel, siis kasutatakse nendes mina- või mitme allkirjastaja korral meie-vormi. Seetõttu tuleb kirjutaja isik avaldustes selgelt esile. Küll aga on avalduste kirjutajad valinud vallavalitsuse tegevuse kirjeldamiseks sageli umbisikulise tegumoe vormid või on nad tegija muul viisil tekstist taandanud. Eri võimalusi on oskuslikult kombineeritud järgmises lõigus.

(10) 15 detsember 2011 toimus Sauga vallas Urge külas üldplaneeringu tutvustav koosolek, mille käigus arutati tuulepargiga seonduvat. Antud koosolekul käis vald välja uue üldplaneeringu kaarti, mis vähendas märkimisväärselt esialgselt tuulikute püstitamiseks ettenähtud piirkonda. Kahjuks tuleb tõdeda, et tuuleenergeetika arenduseks sobivatest aladest jäeti välja ka minule kuuluv Raja kinnistu. Üllatusin mõne võrra, kui niigi väike tuulepargi ala veelgi kitsamaks jäi

Näite 10 esimeses lauses on kasutatud iseeneslikku protsessiverbi toimuma ning pealausele järgnevas kõrvallauses umbisikulist tegumoodi (arutati). Seevastu teine lause sisaldab kaht aktiivset tegijat: pealauses on tegijaks kollektiivne vald (vald käis välja kaardi) ja kõrvallauses isikustatud kaart (kaart vähendas piirkonda). Vaid üksikutes avaldustes esitatakse tegija individualiseeritult, kasutades ametinimetust, kuid mitte ees- ja 
perekonnanime (Sauga vallavolikogu esimees). Näite 10 kolmandas lauses on avalduse kirjutaja kasutanud modaalverbi tuleb (tõdeda), mis on võimaldanud tal enda isik tagaplaanile jätta, niisamuti ei selgu umbisikulise tegumoe tõttu tegija kõrvallausest (jäeti välja). Neljas lause algab oleviku ainsuse esimese pöörde vormiga üllatusin, mis viitab üheselt tegijale, kuid kõrvallause annab edasi automaatset toimumisprotsessi (ala jäi kitsamaks), jättes mulje, et ala kitsenes iseeneslikult. Sellise keelekasutuse taga võib aimata teadlikke valikuid. Kuna nii avalduse esitaja kui ka saaja teavad, kes on üldplaneeringut muutnud ja mis koosolekul toimus, on tegija asemel tähtsam nimetada tegu, mida oodatakse.

\subsection{Enda seisukoha rõhutamine}

Vallavalitsuse ametnike tunnetele apelleerimine ja hinnangusõnade kasutamine taustteabe esitamisel on kaudne viis väljendada rahulolematust olukorraga. Et oma seisukoht selgemini teatavaks teha, järgneb taustteabele sageli lause või lõik, kus avalduse esitaja ütleb otsesõnu, et ta ei ole üldplaneeringus tehtud muudatustega nõus (näide 11).

(11) Sellise muudatusega ei saa me aga nõustuda.

Vastuseisu pehmendamiseks kasutatakse saatelauset, milles avalduse kirjutaja kommenteerib iseenda tegevust. Enamasti nimetab ta seda teatamiseks (näide 12), seejuures eelneb sõnale teatan kaasaütlevas käändes sõna käesolev. Kuigi avaldused on kirjutatud lihtsas üldkeeles, loob selline kantseliitlik sõnavalik intertekstuaalse silla avalduste ja muude ametitekstide, eriti volikirja vahele. Kui aga arvamust avaldatakse sõnadega olen seisukohal ja leian (näide 13), siis ei tavatseta sõna käesolev nende ette lisada.

(12) Käesolevaga teatan, et ei nõustu Sauga valla uue üldplaneeringu lahendusega ..

(13) Leian, et Sauga Vallavalitsus ei ole järginud seaduse põhimõtteid, põhjendamatult vähendades tuulepargi territooriumi.

Seisukohta väljendava lause teises pooles nimetatakse vahel ka tegu, mida vallavalitsus peaks avalduse kirjutaja arvates tegema. Selge muster joonistub sõnadest teatan ja soovin: peale oma seisukoha teatamise esitab avalduse kirjutaja sealsamas soovina ka lahenduse (näide 14). Selline esitusviis on kooskõlas lakoonilisuse taotlusega, sest puudub vajadus alustada 
oma sooviavaldust viidetega eelnevatele tekstilõikudele, nt Eeltoodust tulenevalt .., Juhindudes eeltoodust . .

(14) Käesolevaga teatan, et ma ei nõustu sellise lahendusega ning soovin, et ka minu kinnistu reserveeritakse tuuleenergeetika jaoks sobilikuks alaks.

\subsection{Soovitava teo nimetamine}

Et avalduse saaja ehk vallavalitsus tegutseks avalduse esitaja ehk kodaniku jaoks sobival viisil, tuleb rakendada strateegiat, mis vastab kultuurikontekstis väljakujunenud tavadele. Vaatlusalustes avaldustes on võrdselt esindatud nii palumis- kui ka soovimisstrateegia, üksikjuhtudel esitatakse tegu kas ettepaneku või käsu kujul.

Kui soovitav tegu on vormitud palveks, kasutatakse verbi paluma koos da-infinitiivi vormiga (näide 15), harva koos et-kõrvallausega (näide 16). Verbi paluma kaudu väljendab kodanik oma viisakat suhtumist vallavalitsusse (palun kui viisakusvormel), ühtlasi tugevdab ta sellega vallavalitsuse võimupositsiooni. Seejuures ei sisalda palve osutust tegevuse adressaadile, sest palve täitmist oodatakse vaikimisi avalduse saajalt, kelle andmed on esitatud teksti ülaosas. Erandiks on näide 15, kus vallavalitsust on tegevuse adressaadina sõnaselgelt nimetatud.

(15) Eeltoodust tulenevalt palun Sauga Vallavalitsusel arvestada inimeste õiguspärast ootust ning mitte vähendada 10.06.2009 a. esitletud Valla üldplaneeringu lahendust reserveeritud tuulepargi piirkonna osas.

(16) Eeltoodust tulenevalt palun, et

1. tühistatakse 15.12.2011 a. Urge küla raamatukogus esitletud uus Sauga valla üldplaneeringu lahendus tuulepargi territooriumi vähendamise osas ..

Peale verbi paluma kasutatakse avaldustes ka verbi soovima, millele järgneb et-kõrvallause, mis sisaldab kas tingiva või kindla kõneviisi umbisikulise tegumoe vormi (näide 17). Verbiga paluma võrreldes mõjub soovima rangemana ning tasakaalustab avalduse kirjutaja ja saaja positsiooni. Sedasama teeb substantiivi soov ja $d a$-infinitiivi konstruktsioon (näide 18). Soovi rangust rõhutatakse sõnaga tungiv.

(17) Soovin, et minule kuuluv kinnistu nimetusega Indriko, katastritunnusega 73001:007:0207 reserveeritakse tuuleenergia tootmiseks mõeldud maaalaks ning tähistatakse koostatavas üldplaneeringus piirkonnana, kuhu on lubatud rajada tuuleelektrijaamu. 
(18) Eeltoodust tulenevalt avaldame tungivat soovi, mitte vähendada Sauga valda planeeritud tuuleenergia tootmiseks reserveeritud piirkonda ning ning jääda 10.06.2009 a. esitletud reserveeritud alade juurde.

Avaldustes ei piirduta üksnes palve ja sooviga, vaid tehakse ka ettepanekuid. Kui palve korral seab avalduse esitaja ennast avalduse saajast madalamale ja soovi korral kõrgemale positsioonile, siis ettepaneku tegemisel on osaliste rollid võrdsemad. Ettepaneku korral käib kodanik vallavalitsusele välja mõtte, mida vallavalitsus peab kaaluma, kuid mitte ilmtingimata täitma. Vahel kasutatakse sõna ettepanek ka oma soovi või palve sissejuhatamiseks (näide 19).

(19) Tuginedes eeltoodule eeltoodust teen käesolevaga ettepaneku:

Palun minule kuuluv ELBI kinnistu, katastriüksusega: 73001:007:0245; 73001:007:0244 ja 73001:007:0243, asukohaga Pärnumaa Sauga vald Rütavere küla Elbi reserveerida kui maatulundusmaa, kuhu on lubatud rajada tuuleelektrijaamu.

Soovitavat tegu antakse edasi ka $d a$-infinitiivi tarindite kujul (näide 20). Kuigi käsku üritatakse leevendada tausta selgitamisega eelmistes lõikudes, millele osutab alltoodud näites sõna seega, mõjub selline esitusviis siiski järsuna.

(20) Seega,

reserveerida ka uuel Sauga valla üldplaneeringu kaardil minule kuuluv kinnistu nimega Juntsi-Jüri, katastriüksuse tunnustega 73001:007:0103 ja 73001:007:0105 tuuleenergia tootmiseks sobivaks maaalaks ning märgistada see üldplaneeringusse kui maatulundusala kuhu on lubatud rajada tuuleelektrijaamu.

Niisiis kujundab kodanik kasutatavate keelevahendite abil võimusuhteid. Palve korral seab ta ennast vallavalitsusest madalamale positsioonile, sest palve on leebe soov, mille täitmist vallavalitsuselt oodatakse. Erinevalt palvest on ettepaneku korral võim võrdsemalt jagunenud, kuid jäme ots jääb siiski vallavalitsuse kätte: kuigi ta kohustub ettepanekut kaaluma, võib ta selle ka tagasi lükata. Seevastu oma soovi väljendamine mõjub vaatlusalustes avaldustes nõudena ja $d a$-infinitiivi tarindid käsuna, mille korral on kaalukauss kodaniku poole kaldu. 


\section{Kokkuvõttev arutelu}

Avaldus on tekstiliik, mille suhtluseesmärk ilmneb avalduse esitaja soovis mõjutada avalduse saajat tegema mõnd tegu. Kõrvaleesmärgid on olukohased, sõltudes konkreetse avalduse sisust. Vaatlusalustes avaldustes pöörduvad kodanikud kohaliku omavalitsuse poole, et too muudaks valla üldplaneeringut nii, et ka nende kinnistud jääksid tuulepargi alale, nagu oli esialgu plaanitud. Kuna selline tegevus on kodanikele majanduslikult kasulik, võib avalduste üheks kõrvaleesmärgiks pidada rahalise kasu saamist. Teine kõrvaleesmärk on väljendada oma rahulolematust olukorraga, millesse on avalduse esitajad sattunud avalduse saaja ehk kohaliku omavalitsuse tegevuse tõttu.

Peale otseste eesmärkide võivad tekstid sisaldada ka varjatud eesmärke. Vaatlusaluste avalduste varjatud eesmärgiks võib pidada avalduse rahuldamisega kaasneva rahalise kasu toomist ettevõttele, kes hakkab tuuleparki rajama. Ettevõtte roll näib esmapilgul marginaalne, sest enamikus avaldustes on piirdutud üksnes osutusega, et avalduse esitaja on sõlminud mõningaid lepinguid ja muid kokkuleppeid, mainimata seejuures, kes on teine lepingupool. Vaid ühes analüüsitud avalduses on teist lepingupoolt nimeliselt mainitud (näide 21).

(21) Olen sõlminud Eurowind OÜ-ga notariaalsed hoonestusõiguse seadmise, jm lepingud ja kokkulepped seoses tuulegeneraatorite paigaldamisega minu kuuluvatele kinnistutele.

Kuna avalduste esitajatega ei ole võimalik ühendust võtta, et uurida nende käest tekstistrateegia valiku tagamaid ${ }^{5}$, võib üksnes spekuleerida põhjuste üle, miks on teine lepingupool tekstist taandatud. Üks põhjus võib olla see, et teise lepingupoole nimetamist pole peetud vajalikuks, sest tegu, mida

5 Kuigi informantidega konsulteerimine (Bhatia 1993) või asjaosaliste küsitlemine (Bhatia 2008) pakuks uurimistulemuste tõlgendamiseks vajalikku lisateavet, ei olnud praegusel juhul neid teabehankimisviise võimalik kasutada, sest avalduste esitajad olid eraisikud, mitte ametnikud. Kuna artikli allikmaterjali hulka ei kuulunud vallavalitsuse vastused esitatud avaldustele, sest need ei olnud veebis kättesaadavad, ja avaldustes tehti etteheiteid just vallavalitsuse tegevuse kohta, ei tulnud ka vallavalitsuse ametnike poole pöördumine kõne alla. Seetõttu kogusin taustteavet Sauga vallavalitsuse veebilehel (http://www.sauga.ee/Kirjad-paerast15-12-2010-arut.342.0.html) esitatud teemakohastest dokumentidest, mille hulka kuuluvad mitmesugused päringud, teabenõuded, märgukirjad, taotlused, ettepanekud, protokollid jms. 
kohalikult omavalitsuselt oodatakse, ei olene sellest, kellega on lepingud sõlmitud. Teine põhjus on risti vastupidine: teist lepingupoolt kui võimalikku häirivat tegurit pole nimme tekstis mainitud, sest tuulepargi rajamine on seotud ka kohaliku omavalitsuse, tuuleparki rajada sooviva ettevõtte ja tuulepargivastaste kodanike vahelise võimuvõitlusega, mistõttu ei soovi avalduse esitaja kohaliku omavalitsuse poole pöördudes rohkem õli tulle valada. Sellest võimuvõitlusest annavad aimu sama teema kohta käivad dokumendid, mis on samuti esitatud valla veebilehel.

Eelnimetatud eesmärke püütakse saavutada asjakohase tekstistrateegiaga, mis ilmneb teksti astmelises struktuuris ja eripärastes tekstimustrites. Obligatoorseid struktuurielemente esindavad kaks käiku: taustteabe esitamine, mis koosneb kolmest sammust (aja ja koha väljendamine, enda seotus kõnealuse probleemiga ja probleemi kirjeldamine), ning soovitava teo nimetamine. Fakultatiivseks elemendiks võib pidada enda seisukoha rõhutamist. Kuigi astmeline struktuur on vaatlusaluste lepingute puhul üsna standardne, varieerub käikude ja sammude järjekord. Kõige sagedamini esitatakse avalduse alguses esmalt taustteave, kirjeldades, millal ja kus probleem ilmnes, kuidas on avalduse esitaja probleemiga seotud ning milles probleem seisneb, seejärel väljendatakse oma seisukohta ja lõpuks nimetatakse soovitav tegu. Ühelt poolt tuleneb selline standardne struktuur žanritavadest. Kuna avaldused on traditsiooniliselt võrdlemisi lühikesed (kuni ühe lehekülje pikkused), siis ei ole käikude ja sammude mitmekesistamiseks kuigi palju võimalusi. Teiselt poolt võib sisu ühetaolisus olla tingitud avalduste esitajate kokkulepetest, mis on tõenäoline, arvestades, et avaldused on esitatud lühikese ajavahemiku jooksul ja esitajad on ühe kandi inimesed. ${ }^{6}$

Olgugi et avalduste astmeline struktuur varieerub vähe, tulevad erinevused esile tekstimustrites. Avalduste sisu vormistatakse peamiselt kas palve või soovina, kasutades sõnu palun, soovin ja soov. Mõnel üksikul juhul pöördub kodanik kohaliku omavalitsuse poole ettepaneku või käsu vormis. Kuna avaldus on kirjutaja enda huvides, ei peeta otsest kohustamist sobilikuks. Kodaniku nõue või käsk mõjuks järsuna ja žanritavade rikkumisena, mistõttu võib see tekitada ametiasutuse vastuseisu.

Nii nagu jäävad kodanikud vaoshoituks soovitava teo nimetamisel, hoitakse sama joont ka pahameele väljendamisel. Sellele, et kohaliku

6 Et saada põhjalikumat ülevaadet avalduse kui tekstiliigi eriomaste tunnuste kohta, tuleks edasistes uurimustes allikmaterjali hulka laiendada ja mitmekesistada. 
omavalitsuse tegevusega ei olda rahul, osutavad kodanikud vaid ääri-veeri: näpuga näitamise ja otsese kriitika asemel antakse vihjamisi märku, et ametiasutuse tegevus (üldplaneeringu muutmine) jääb neile arusaamatuks või on üllatav. Süüdlast ei otsita, nimesid ei nimetata. Enamasti piirdutakse umbisikulise tegumoega, harva mainitakse vallavalitsust kui kollektiivset tegijat. Selline strateegiavalik on ootuspärane, arvestades, et see, kelle teguviisiga ei olda rahul ja kellele esitatakse avaldus, on üks ja seesama (kollektiivne) isik. Hoopis teisiti toimitakse aga siis, kui süüdi on keegi teine (näited 22 ja 23).

(22) Olen andnud allkirja detsembris 2011 Sauga Vallavalitsusele esitatud taotlusele, seoses Sauga valla üldplaneeringu koostamisega, milles on palutud Urge, Pulli ja Rütavere külla tuuleparki mitte rajada. Vastava avalduse teksti esitas mulle Tõnu-Rasmus Põldvee, kes käis isiklikult minu juure, kui ma olin haiguse tõttu ebaadekvaatses olekus. Ma ei saanud kõigest Põldvee jutust õigesti aru. Ta rääkis midagi taolist, et Eurowind on mind eksitanud ja palus paberitele alla kirjutada. Samuti väitis Põldvee, et ma ei ole enam oma kinnistu omanik, see kuulub nü̈d Eurowindile ja mina saan Eurowindiga sõlmitud hoonestusõiguse lepingutest kahju.

(23) Seoses tuulepargi ehitamisega Vanamõisa talumaadele. Tuldi otsekohe pettusega. Maksame ilusat suurt raha, 300 eurot. Maamaksu maksame. Aeg läheb, tulevad mingisugused noored. Anna meile allkiri, et sa tahad ikka tuuleparki. Oli esimene küsimus kus on lepingu sõlmija. Ei ole. Meie ise teeme. Oleme Sõnajalad, minu vastus oli juba neile. Sõnajalgade jutt hakkab selgeks saama käivad kohtus, petetakse vanu inimesi, anna maa rendile, tagatiseks. Mida mina ei lugenud ridade vahelt välja. Peale selle laulavad kiriku laule et jumal aitab. See on puhas pettus jumal ei ehita ühtegi tuulikut. Jumal lõi kuue päevaga maa ja taeva.

Need tekstikatked ei pärine artikli allikmaterjalist, vaid avaldustest, mis on esitatud Sauga vallavalitsusele aasta hiljem (jaanuaris ja märtsis 2012). Erinevalt varasematest avaldustest, mille esitamise põhjused tulenevad rahulolematusest vallavalitsuse tegevusega, on nende aluseks avalduse esitaja enda tegevus. Seetõttu rakendatakse vallavalitsuse poole pöördumisel hoopis teistsugust taktikat: kolmandat osalist näidatakse enda kaassüüdlasena (näide 22) või veeretatakse kogu süü tema kaela (näide 23). Selline teguviis kinnitab ka eespool esitatud oletust, et taktikalistel põhjustel - tugevate huvikonfliktide tõttu - pole kinnistu omanikud avaldustes maininud, kellega nad on tuulepargi rajamiseks lepingud sõlminud. 
Eeltoodust ilmneb, et vaatlusalused avaldused on võrdlemisi jäiga sisemise struktuuriga, mis tuleneb ühtaegu nii kultuurikontekstist (žanritavadest) kui ka situatsioonikontekstist (konkreetsest olukorrast ja osalistevahelistest suhetest). Kuna žanritunnused tulevad kõige paremini esile eri tekstide võrdlusest, siis pakuks praeguste avalduste võrdlemine teist tüüpi avaldustega väärt uurimisainest. Lisaks vääriks uurimist, mille poolest erinevad avaldused taotlustest, kaebekirjadest jms tekstidest, mis vähemasti nimetuse poolest esindavad eri tekstižanre.

\section{Kirjandus}

Askehave, Inger 1999. Communicative purpose as genre determinant. - Hermes 23, 13-23. http://download2.hermes.asb.dk/archive/FreeH/H23_02.pdf.

Askehave, Inger, John Swales 2001. Genre identification and communicative purpose: a problem and possible solution. - Applied Linguistics 22 (2), 195-212.

Bawarshi, Anis S., Mary Jo Reiff 2010. Genre. An introduction to history, theory, research, and pedagogy. - Reference Guides to Rhetoric and Composition. Ed. Charles Bazerman. West Lafayette: Parlor Press, WAC Clearinghouse.

Bhatia, Vijay Kumar 1993. Analysing Genre. Language Use in Professional Settings. Applied Linguistics and Language Studys. New York: Longman.

Bhatia, Vijay Kumar 2008. Towards critical genre analysis. - Advances in Discourse Studies. Eds. Vijay K. Bhatia, John Flowerdew, Rodney H. Jones. Abingdon: Routledge, 166-177.

Bhatia, Vijay Kumar 2015. Critical genre analysis: theoretical preliminaries. Hermes 54, 9-20. http://ojs.statsbiblioteket.dk/index.php/her/article/ view/22944/20054.

Hyland, Ken 2002. Genre: language, context and literacy. - Annual Review of Applied Linguistics 22, 113-135. http://dx.doi.org/10.1017/ S0267190502000065.

Hyon, Sunny 1996. Genre in three traditions: implications for ESL. - Tesol Quarterly 30 (4), 693-722. http://dx.doi.org/10.2307/3587930.

Kerge, Krista 2010. Kirjažanrite keeleparameetrid mitme tekstiliigi taustal. Emakeele Seltsi aastaraamat 55 (2009). Peatoim. Mati Erelt. Tallinn: Teaduste Akadeemia Kirjastus, 32-62.

Lassen, Inger 2006. Is the press release a genre? A study of form and content. Discourse Studies 8, 503-530.

Lepajõe, Kersti 2011. Kirjand kui tekstiliik. Riigieksamikirjandite tekstuaalsed, retoorilised ja diskursiivsed omadused. (= Dissertationes philologiae estonicae Universitatis Tartuensis 31.) Tartu: Tartu Ülikooli Kirjastus. 
Martin, James Robert 2001. Language, register and genre. - Analysing English in a Global Context: A Reader. Eds. Anne Burns, Caroline Coffin. London: Routlege, Macquarie University, The Open University, 149-166.

Puksand, Helin, Krista Kerge 2012. Õpiteksti analüüs kirjaoskuse omandamise kontekstis. - Emakeele Seltsi aastaraamat 57 (2011). Peatoim. Mati Erelt. Tallinn: Teaduste Akadeemia Kirjastus, 162-217. http://dx.doi. org/10.3176/esa57.09.

Pullerits, Egle 2005. Ametikiri kui tekst: struktuur ja keelekasutus. Bakalaureusetöö. Tartu Ülikool. Eesti keele õppetool. Juhendaja dotsent Reet Kasik. Tartu: Tartu Ülikool.

Raadik, Maire 2014. Väikesed tarbetekstid. Käsiraamat. Teine, täiendatud trükk. Eesti Keele Instituut. Tallinn: Eesti Keele Sihtasutus.

Ratassepp, Katre 2016. Inimeste kogemus suhtlusest ametiasutustega kirjade arusaadavuse näitel. Magistritöö. Tallinn: Tallinna Ülikool.

Reinsalu, Riina 2011. Leping tekstiliigina: žanristruktuur. - Eesti Rakenduslingvistika Ühingu aastaraamat 7. Toim. Helle Metslang, Margit Langemets, Maria-Maren Sepper. Tallinn: Eesti Rakenduslingvistika Ühing, 215-229. http://dx.doi.org/10.5128/ERYa7.13.

Rätsep, Siret 2006. Ametikirja vorm ja keel ühe riigiasutuse näitel. Magistritöö. Tallinn: Tallinna Ülikool.

Swales, John Malcolm 1990. Genre Analysis. English in Academic and Research Settings. Cambridge Applied Linguistics series. Cambridge: Cambridge University Press.

Swales, John Malcolm 2012. A text and its commentaries: toward a reception history of „Genre in three traditions“" (Hyon, 1996). - Iberica 24, 103-116.

Tardy, Christine M. 2013. Genre analysis. - The Bloomsbury Companion to Discourse Analysis. Eds. Ken Hyland, Brian Paltridge. London etc.: Bloomsbury.

Tardy, Christine M., John Swales 2014. Genre analysis. - Pragmatics of Discourse. Eds. Klaus P. Schneider, Anne Barron. Handbooks of Pragmatics. Berlin, New York: Mouton de Gruyter, 165-188. http://dx.doi. org/10.1515/9783110214406-007.

Tomiste, Sirje 2012. Ametikirjade keeleparameetrid. Magistritöö. Tallinna Ülikool. Eesti keele ja kultuuri instituut. Tallinn: Tallinna Ülikool. 


\title{
Textual strategies of applications
}

\author{
RIINA REINSALU
}

Professional and administrative communication requires the creation of different types of texts. While some of them merely serve the purpose of preserving information, others are intended to influence people's actions. In this article, I will explore applications as a textual genre based on 19 applications presented to Sauga Municipality. My goal is to find out what kind of generic structure these applications have and by what linguistic means the applicants aim to direct the actions of those who receive them. Since the applicants are citizens and the receiver is a state authority, the analysis of textual strategies also sheds light on practices between citizens and local authorities as well as on possible power relations between them.

The structural analysis of the applications reveals that they have a somewhat rigid generic structure stemming from the tradition of the genre, the particular communicative situation, and the relations between the applicants and the receiver. Applications, in general, are based on two obligatory moves (presenting background information and naming the desired action) and an optional move (expressing one's point of view). In addition, in presenting the background information, we can distinguish between three steps: one can elaborate when and where the problem occurred, how the applicant is related to the problem, and what in fact is the problem. While the general structure of the analyzed applications is fairly standardized, some differences can be detected in the particular order of moves and steps.

The choices of strategies in applications appear in certain textual patterns. The content of an application is usually either a request or wish and expressed as I request, I wish, and wish. In some rare cases, citizens also use propositions or orders in communicating with their local government. Since the application is in the applicant's own best interest, a direct obligating or coercive approach is usually found inappropriate. The citizen's demand or order would come across as harsh and as violating the traditions of the genre, and in doing so would create unnecessary opposition from state authorities and thereby undermine the communicative purpose of the application: influencing the receiver to perform the act desired by the applicant.

Keywords: language of documents, structural analysis, genre, genre analysis, Estonian 
Riina Reinsalu

eesti ja üldkeeleteaduse instituut

Tartu Ülikool

Jakobi 2

51014 Tartu

riina.reinsalu@ut.ee 